\title{
Cubo mágico estrátegia para o ensino da matemática
}

\section{Magic cube for the teaching of mathematics}

DOI: 10.46814/lajdv3n1-011

Recebimento dos originais: 30/10/2020

Aceitação para publicação: 11/01/2021

\author{
Brenda Lorranny Cerqueira da Silva \\ Estudante do Colégio Estadual CEEPGTI Álvaro Melo Vieira \\ E-mail: lorrannycds@gmaisl.com \\ José Raimundo Almeida Campo \\ Estudante do Colégio Estadual CEEPGTI Álvaro Melo Vieira \\ E-mail: joseraimundo_ac@ hotmail.com \\ Maria Angélica Santos Souza \\ Professor do Colégio Estadual CEEPGTI Álvaro Melo Vieira \\ E-mail: mara-angel@hotmail.com
}

\begin{abstract}
RESUMO
O presente trabalho trata da importância do uso dos jogos para a aprendizagem de matemática no Ensino Médio, apresentando sugestões práticas de como utilizar os jogos para facilitar o desenvolvimento e o raciocínio lógico dos alunos com dificuldades em aprendizagem. O cubo Mágico é um jogo que de forma dinâmica pode contribuir na aprendizagem matemática do aluno. $\mathrm{O}$ objetivo desse trabalho é dinamizar o processo de aprendizagem de matemática através de jogos de raciocínio lógico e desafiar os alunos para provar que os mesmos têm a capacidade de aprender. A matemática é uma disciplina de suma importância em várias situações em nossa vida, se olhar ao nosso redor pode notar sua presença nos contornos, nas formas dos objetos, nas medidas de comprimento, além de ser usada para medir ou calcular, e utilizado para ensino prático usando jogos com apoio e prática incentivando o aluno a aprender. A metodologia aplicada a esse trabalho deu-se através da adaptação de um cubo mágico com algarismos para efetuar as operações. A finalidade desse jogo é montar o cubo de acordo com a operação adição, fazendo com que todos os números somados de uma face, exceto o que está localizado no meio da face, seja igual ao número central do cubo. Nesse ano de 2015 foi criado um protótipo de um cubo mágico com operações matemáticas para trabalhar o raciocínio lógico. Será apresentado alguns tutoriais para sua montagem, este será etiquetado com números que somados darão o resultado do centro de cada face. A aprendizagem da Matemática depende de uma grande variedade de fatores o que torna o seu ensino bastante complexo. É necessário desenvolver o raciocínio lógico e estimular o pensamento independente, a criatividade e a capacidade de resolver problemas. Neste trabalho começamos por apresentar as vantagens do uso dos jogos no ensino da matemática, tendo em vista a sua importância na aprendizagem da matemática. Espera-se que esse trabalho com o uso de jogos matemáticos possa contribuir de forma articulada para o desenvolvimento da aprendizagem matemática.
\end{abstract}

Palavras chaves: Matemática, Jogos, Cubo Mágico. 


\begin{abstract}
This paper deals with the importance of the use of games for learning mathematics in high school, presenting practical suggestions on how to use games to facilitate the development and logical reasoning of students with learning difficulties. The Magic Cube is a game that in a dynamic way can contribute to the student's math learning. The objective of this work is to dynamize the math learning process through logical reasoning games and to challenge students to prove that they have the ability to learn. Mathematics is a subject of paramount importance in many situations in our lives, if you look around you can notice its presence in the contours, shapes of objects, length measurements, in addition to being used to measure or calculate, and used for practical teaching using games with support and practice encouraging the student to learn. The methodology applied to this work was through the adaptation of a magic cube with numbers to perform the operations. The purpose of this game is to assemble the cube according to the add operation, making all the numbers added from one face, except the one located in the middle of the face, be equal to the central number of the cube. In this year 2015 was created a prototype of a magic cube with mathematical operations to work the logical reasoning. Some tutorials will be presented for its assembly, it will be labeled with numbers that added together will give the result of the center of each face. The learning of mathematics depends on a great variety of factors which makes its teaching quite complex. It is necessary to develop logical reasoning and stimulate independent thinking, creativity and the ability to solve problems. In this work we begin by presenting the advantages of the use of games in the teaching of mathematics, in view of their importance in the learning of mathematics. It is hoped that this work with the use of mathematical games can contribute in an articulated way to the development of mathematical learning.
\end{abstract}

Keywords: Mathematics, Games, Magic Cube.

\title{
1 INTRODUÇÃO
}

A matemática é uma ciência de fundamental importância nos dias atuais devido a sua lógica, raciocínio, capacidade de desenvolver habilidades cognitivas. Tem grande importância na formação acadêmica e profissional do indivíduo. Os estudantes têm o primeiro contato com a matemática através de jogos lúdicos ou brincadeiras, conforme avançam os níveis escolares vão perdendo o contato com os jogos e a disciplina passa a não ser tão prazerosa para a maioria. O IDEB é um indicador da qualidade da educação no Brasil que utiliza uma escala que vai de 0 a 10, sendo 6,0 a média que corresponde a uma educação de qualidade em relação a países desenvolvidos. Infelizmente a rede pública não atingiu a média 6,0. É facilmente perceptível o desinteresse de grande parte dos alunos de uma escola por matemática. Esse desinteresse é comum, entretanto não é um problema impossível de solucionar. Já existem vários métodos de tornar a disciplina mais dinâmica, divertida e interessante, um deles é a utilização de jogos para atrair o aluno para determinadas áreas da matemática. Portanto a proposta desse trabalho é desenvolver um jogo de raciocínio lógico com operações matemáticas para atrair a atenção dos alunos principalmente do ensino médio e inspirar novas adaptações ou criações de jogos lúdicos que possam contribuir com a aprendizagem. Esse projeto tem uma grande importância pois, gera uma contribuição significativa para o processo de aprendizagem e raciocínio dos alunos, 
facilitando a interação com a matemática e para aplicação de novas metodologia nas aulas de matemática.

\subsection{HIPÓTESE}

A dificuldade de aprender matemática e o desinteresse dos alunos pode ser comum devido à falta de entendimento e gosto pela matemática. Acredito se nas aulas de matemática fossem desenvolvidas com alguns jogos e desafios tornaria a matéria mais dinâmica e agradável despertando o interesse e envolvimento dos alunos pela disciplina.

\section{OBJETIVOS}

\subsection{OBJETIVOS GERAIS}

Dinamizar o processo de aprendizagem de matemática através de jogos de raciocínio lógico e desafiar os alunos para provar que os mesmos têm a capacidade de aprender.

\subsection{OBJETIVOS ESPECÍFICOS}

- Melhorar o rendimento dos alunos na disciplina;

- Garantir o interesse pela disciplina de matemática;

- Reaproveitar jogos e desafios para o desenvolvimento de novas atividades de lazer relacionada com a disciplina;

- Desafiar os alunos e mostrar que eles são capazes de integrar com a prática a lógica matemática.

\subsection{PROBLEMA}

De que forma o uso de jogos na disciplina de matemática pode contribuir com a aprendizagem dos alunos?

\section{METODOLOGIA}

A metodologia dar-se-á através de pesquisa bibliográfica, e adaptação do cubo mágico com algarismos para efetuar as operações e realizações de testes. O objetivo do jogo é montar o cubo de acordo com a operação adição, fazendo com que todos os números somados de uma face, exceto o que está localizado no meio da face, sejam iguais ao número central do cubo. 


\section{APRESENTAÇÃO E DISCUSSÃO DOS RESULTADOS}

Não foi possível obter resultados ainda, porém já foram realizados alguns testes e essa etapa ainda não foi concluída.

\section{CONCLUSÕES}

O projeto do cubo matemático está em andamento. Entretanto é esperado que o mesmo seja capaz de contribuir nas aulas de matemática e atrair a atenção e o interesse dos alunos pela disciplina.

\section{AGRADECIMENTOS}

A equipe do Centro Estadual de Educação Profissional e Gestão em Tecnologia da Informação Álvaro Melo Vieira pela estrutura e apoio.

Às professoras Maria Angélica, Margarete Araújo e Maria Iracy Lacerda pela paciência e orientação. A família pelo apoio e compreensão.

Aos colegas e amigos que contribuíram para que nossos objetivos fossem alcançados. 


\section{REFERÊNCIAS}

Matemática : ciência e aplicações, volume 2 : ensino médio / Gelson Iezzi..[et al.].— 7 . Ed.— São Paulo : Saraiva, 2013.

Tahan, M. O Homem Que Calculava. 63ed. Brasil: Saraiva, 2003, 300p. SMOLE, K.S.; DINIZ, M.I; MILANI, E.

Jogos de matemática do $6^{\circ}$ ao $9^{\circ}$ ano. Cadernos do Mathema. Porto Alegre: Artmed 2007. 